\title{
Halococcus thailandensis sp. nov., from fish sauce in Thailand
}

Correspondence

Somboon Tanasupawat Somboon.T@chula.ac.th

\author{
Sirilak Namwong, ${ }^{1}$ Somboon Tanasupawat, ${ }^{1}$ Wonnop Visessanguan, ${ }^{2}$ \\ Takuji Kudo ${ }^{3}$ and Takashi Itoh ${ }^{3}$
}

\author{
${ }^{1}$ Department of Microbiology, Faculty of Pharmaceutical Sciences, Chulalongkorn University, \\ Bangkok 10330, Thailand \\ ${ }^{2}$ National Center for Genetic Engineering and Biotechnology, Pathumthani 12120, Thailand \\ ${ }^{3}$ Japan Collection of Microorganisms, RIKEN BioResource Center, 2-1 Hirosawa, Wako-shi, \\ Saitama 351-0198, Japan
}

The genus Halococcus was first proposed by Schoop (1935) to accommodate red, extremely halophilic cocci that thrive in hypersaline environments, and the generic name was implemented by Kocur \& Hodgkiss (1973) with the proposal of a single species, Halococcus morrhuae. In addition to Hcc. morrhuae, the genus Halococcus currently comprises five other recognized species, Halococcus saccharolyticus, Hcc. salifodinae, Hcc. dombrowskii, Hcc. hamelinensis and Hcc. qingdaonensis (Montero et al., 1989; Denner et al., 1994; Stan-Lotter et al., 2002; Goh et al., 2006; Wang et al., 2007). Fish sauce (nam-pla) fermentation in Thailand has also provided isolation sources of novel halophilic archaea and bacteria, for example Halobacterium salinarum, Halobacillus thailandensis, Tetragenococcus halophilus, Tetragenococcus muriaticus, Lentibacillus salicampi, Lentibacillus juripiscarius and Lentibacillus halophilus (Chaiyanan et al., 1999; Tanasupawat \& Komagata, 2001; Thongthai et al., 1992; Thongsanit et al., 2002; Namwong et al., 2005; Tanasupawat et al.,

The GenBank/EMBL/DDBJ accession number for the 16S rRNA gene sequence of strain HDB5-2 $2^{\top}$ is AB220647.
2006). The present study describes the isolation of extremely halophilic archaeal cocci isolated from fish sauce fermentation and their characterization based on phenotypic, chemotaxonomic, DNA-DNA relatedness and $16 \mathrm{~S}$ rRNA gene sequencing data.

The halophilic archaeal strains were isolated from fish sauce samples (nam-pla) collected from factories in Thailand during the early, middle and late stages of the fermentation process by using a spread-plate technique on JCM medium 169 agar plates [consisting of (per litre): $250 \mathrm{~g} \mathrm{NaCl}, 7.5 \mathrm{~g}$ Casamino acids, $10 \mathrm{~g}$ yeast extract, $2 \mathrm{~g}$ $\mathrm{KCl}, 3 \mathrm{~g}$ trisodium citrate, $20 \mathrm{~g} \mathrm{MgSO}_{4} .7 \mathrm{H}_{2} \mathrm{O}, 0.05 \mathrm{~g}$ $\mathrm{FeSO}_{4} .4 \mathrm{H}_{2} \mathrm{O}, 0.2 \mathrm{~g} \quad \mathrm{MnSO}_{4} .4 \mathrm{H}_{2} \mathrm{O}, 20 \mathrm{~g}$ agar, pH 7.2] incubated at $37{ }^{\circ} \mathrm{C}$ for $1-2$ weeks. Unless otherwise stated, the test strains were grown in liquid or on agar medium of JCM medium 169.

Cell morphology of the isolates was observed by light microscopy and scanning electron microscopy for cells grown on agar plates at $37^{\circ} \mathrm{C}$ for 7 days. Tests for general physiological and biochemical characteristics were performed as specified by Oren et al. (1997). Tests for catalase 
and oxidase activities, indole production, nitrate reduction and hydrolysis of casein, gelatin, arginine and Tween 80 were performed as described by Barrow \& Feltham (1993). Carbon utilization and acid production from carbohydrates were determined in modified Leifson medium (Leifson, 1963) supplemented with $0.01 \%$ yeast extract and $20 \%(\mathrm{w} / \mathrm{v}) \mathrm{NaCl}$. Casitone was omitted for the carbon utilization tests and Tris/ $\mathrm{HCl}$ was omitted for the acid production tests. Anaerobic growth was observed in standard growth medium with $0.5 \%$ nitrate or arginine by using a Gaspak (BBL) anaerobic jar. The temperature range for growth was examined by incubating cultures on agar plates at 20,28,37, 45 and $50{ }^{\circ} \mathrm{C}$. Effects of $\mathrm{NaCl}$ concentration for growth were tested in medium containing $0-30 \%(\mathrm{w} / \mathrm{v}) \mathrm{NaCl}$. At lower $\mathrm{NaCl}$ concentrations (0-2\%), $\mathrm{MgSO}_{4} .7 \mathrm{H}_{2} \mathrm{O}, \mathrm{KCl}$ and trisodium citrate were omitted from the test medium. Similarly, the requirement for $\mathrm{Mg}^{2+}$ was tested in JCM 169 medium by omitting $\mathrm{MgSO}_{4} \cdot 7 \mathrm{H}_{2} \mathrm{O}$ but supplementing with $2 \%(\mathrm{w} / \mathrm{v}) \mathrm{Na}_{2} \mathrm{SO}_{4}$ and $0-10 \%(\mathrm{w} / \mathrm{v})$ $\mathrm{MgCl}_{2}$. Growth was determined by measuring culture turbidity at $660 \mathrm{~nm}$. The antibiotic susceptibility of the strains was tested as described by Stan-Lotter et al. (2002). Menaquinones were analysed as described by Komagata \& Suzuki (1987). Polar lipids were determined according to the method of Minnikin et al. (1984).

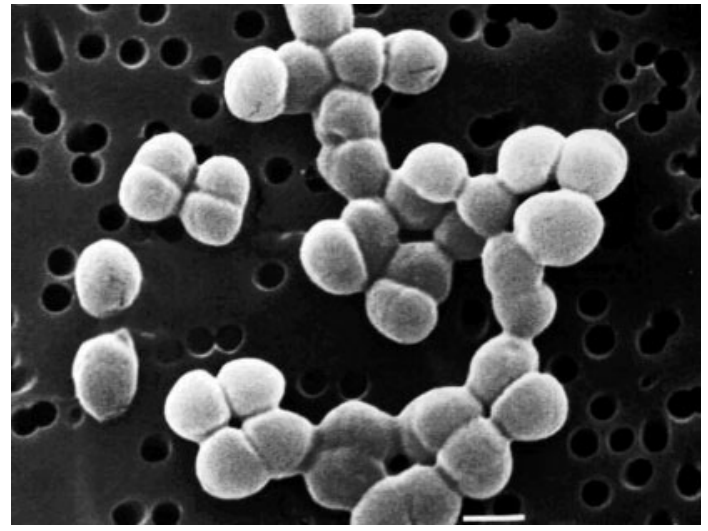

Fig. 1. Scanning electron micrograph of cells of strain HDB5-2 ${ }^{\top}$ grown on JCM 169 medium at $37^{\circ} \mathrm{C}$. Bar, $1 \mu \mathrm{m}$.

DNA was isolated and purified according to the method of Saito \& Miura (1963). The DNA G+C content was determined as described by Tamaoka \& Komagata (1984) by using reversed-phase HPLC. DNA-DNA hybridization tests were performed as described by Ezaki et al. (1989) and levels of relatedness were determined according to

Table 1. Differential characteristics between strain HDB5-2 ${ }^{\top}$ and related Halococcus species

Strains: 1, HDB5-2 ${ }^{\mathrm{T}}$ (identical results produced for 14 other strains); 2, Hcc. dombrowskii JCM 12289 $; 3$, Hcc. morrhuae JCM 8876 ${ }^{\mathrm{T}}$; 4, Hcc. saccharolyticus JCM $8878^{\mathrm{T}}$; 5, Hcc. hamelinensis JCM $12892^{\mathrm{T}}$ (data from Goh et al., 2006); 6, Hcc. salifodinae JCM 9578 ${ }^{\mathrm{T}}$ (data from Denner et al., 1994); 7, Hcc. qingdaonensis JCM $13587^{\mathrm{T}}$ (data from Wang et al., 2007). +, Positive; -, negative; w, weak; ND, no data.

\begin{tabular}{|c|c|c|c|c|c|c|c|}
\hline Characteristic & 1 & 2 & 3 & 4 & 5 & 6 & 7 \\
\hline Optimum $\mathrm{NaCl}(\%, \mathrm{w} / \mathrm{v})$ & $20-30$ & $20-30$ & $20-30$ & $20-30$ & 15 & $20-30$ & 18 \\
\hline Optimum $\mathrm{MgCl}_{2}(\%, \mathrm{w} / \mathrm{v})$ & $0-0.8$ & $0.6-5$ & $0.8-5$ & $\mathrm{ND}$ & $\mathrm{ND}$ & $\mathrm{ND}$ & ND \\
\hline Growth at $\mathrm{pH} 9.0$ & + & - & + & - & + & + & + \\
\hline Growth at $45{ }^{\circ} \mathrm{C}$ & + & - & - & $\mathrm{ND}$ & $\mathrm{ND}$ & ND & ND \\
\hline Oxidase & + & + & + & + & - & + & - \\
\hline Nitrate reduction & $+/$ no gas & $+/$ no gas & $+/$ no gas & + & $+/$ no gas & + & - \\
\hline Indole formation & - & ND & + & ND & - & ND & ND \\
\hline Hydrolysis of gelatin & - & + & - & $\mathrm{v}$ & - & + & - \\
\hline \multicolumn{8}{|l|}{ Acid from: } \\
\hline L-Arabinose & + & $\mathrm{W}$ & - & - & ND & ND & ND \\
\hline Cellobiose & + & - & - & - & $\mathrm{ND}$ & ND & ND \\
\hline D-Glucose & + & - & - & - & + & ND & ND \\
\hline Lactose & + & - & - & - & ND & ND & ND \\
\hline D-Mannitol & + & - & - & - & $\mathrm{ND}$ & ND & ND \\
\hline Melibiose & - & - & - & - & ND & ND & ND \\
\hline Trehalose & + & - & - & - & ND & $\mathrm{ND}$ & ND \\
\hline \multicolumn{8}{|l|}{ Utilization of: } \\
\hline L-Arabinose & $\mathrm{W}$ & + & - & + & $\mathrm{ND}$ & + & ND \\
\hline D-Fructose & + & + & - & + & ND & + & ND \\
\hline D-Glucose & $\mathrm{w}$ & - & - & + & + & + & + \\
\hline D-Galactose & - & + & - & + & + & ND & ND \\
\hline D-Xylose & $\mathrm{w}$ & + & - & - & + & ND & ND \\
\hline Glutamic acid & + & - & - & + & ND & ND & ND \\
\hline Serine & - & - & - & + & ND & ND & ND \\
\hline
\end{tabular}


Tanasupawat et al. (2000). The almost-complete 16S rRNA gene sequence of a representative strain, designated HDB5$2^{\mathrm{T}}$, was amplified by PCR with primers D30F $\left(5^{\prime}-\right.$ ATTCCGGTTCATCCTGC, positions 6-22 according to the Escherichia coli numbering system) and D56R (5'GYTACCTTGTTACGACTT, positions 1492-1509). The amplified DNA fragment was separated by agarose gel electrophoresis and recovered by using a GenElute Minus EtBr spin column (Sigma). The sequence was determined by using the BigDye Terminator cycle sequencing ready reaction kit (version 3.0; Applied Biosystems) in an ABI PRISM 310 Genetic Analyzer (Applied Biosystems) with the following primers: D30F, D33R (5'-TCGCGCCTGCGCCCCGT, positions 344-360), D34R (5'-GGTCTCGCTCGTTGCCTG, positions 1096-1113), D56R, B99R (5'-GTGTTACCGCGGCTGCTG, positions 519-536), B36R (5'-GGACTACCAGGGTATCTA, positions 789806) and X10R (5'-ACGGGCGGTGTGTRC, positions 1392-1406). The phylogenetic tree was constructed as described by Thompson et al. (1994), Saitou \& Nei (1987), Kumar et al. (2001) and Felsenstein (1985).

Fifteen extremely halophilic, Gram-negative cocci were isolated from various stages of the fish sauce fermentation process. Cells of these isolates were non-motile, $0.8-1.2 \mu \mathrm{m}$ in diameter, occurring singly, in pairs or in tetrads (Fig. 1) during both exponential and stationary phases of growth. In addition, the cells did not lyse when suspended in distilled water for 1-2 h. They formed small, red-pigmented colonies
(1-2 $\mathrm{mm}$ in diameter) on agar plates. The isolates grew in medium containing a high concentration of $\mathrm{NaCl}$ [at least $15 \%(w / v)$ and optimally $20-30 \%(w / v)]$. Their growth temperature range was $15-45{ }^{\circ} \mathrm{C}$ (optimum growth at $37{ }^{\circ} \mathrm{C}$ ) and $\mathrm{pH}$ range was $6-10$ (optimum growth at $\mathrm{pH}$ 6-8). The physiological and biochemical properties of strain HDB5- $2^{\mathrm{T}}$ are given in the species description below and in Table 1. A thin-layer chromatogram of the polar lipid fraction from four representative strains, HDS4-1, HDB5-2 ${ }^{\mathrm{T}}$, HDS7-4 and HIS10-2, revealed $\mathrm{C}_{20} \mathrm{C}_{20}$ and $\mathrm{C}_{20} \mathrm{C}_{25}$ diether lipids of phosphatidylglycerol, phosphatidylglycerol methylphosphate, a sulfated diglycosyl diether (S-DGA-1) and unidentified glycolipids, by comparing the profiles with those of Hcc. dombrowskii JCM $12289^{\mathrm{T}}$ and Hcc. morrhuae JCM $8876^{\mathrm{T}}$. Phosphatidylglycerol sulfate was not detected. The novel strains had MK$8\left(\mathrm{H}_{2}\right)$ as the major menaquinone component. The DNA $\mathrm{G}+\mathrm{C}$ contents of the novel strains were $60.0-61.8 \mathrm{~mol} \%$ (Table 2).

Comparison of the 16S rRNA gene sequence (1384 bp) of strain HDB5- $2^{\mathrm{T}}$ with those of representative members of the family Halobacteriaceae revealed that it belonged to the genus Halococcus (Grant \& Larsen, 1989; Grant, 2001). A phylogenetic tree showing the position of strain HDB5- $2^{\mathrm{T}}$ in the genus Halococcus was reconstructed as shown in Fig. 2. Strain HDB5- $2^{\mathrm{T}}$ was closely related to Hcc. morrhuae JCM $8876^{\mathrm{T}}$, Hcc. qingdaonensis JCM $13587^{\mathrm{T}}$ and Hcc. dombrowskii JCM $12289^{\mathrm{T}}$, with $16 \mathrm{~S}$ rRNA gene sequence

Table 2. DNA $G+C$ contents and levels of DNA-DNA relatedness among the 15 novel strains, Hcc. dombrowskii JCM $12289^{\top}$ and Hcc. morrhuae JCM $8876^{\top}$

\begin{tabular}{|c|c|c|c|c|c|}
\hline \multirow[t]{2}{*}{ Strain } & \multirow{2}{*}{$\begin{array}{c}\text { Factory/ } \\
\text { fermentation } \\
\text { time (days) }\end{array}$} & \multirow[t]{2}{*}{$\begin{array}{c}\text { DNA G + C } \\
\text { content }(\mathrm{mol} \%)\end{array}$} & \multicolumn{3}{|c|}{$\begin{array}{l}\text { DNA-DNA relatedness }(\%) \text { with } \\
\text { labelled strain }\end{array}$} \\
\hline & & & JCM $12289^{T}$ & JCM $8876^{T}$ & HDB5-2 ${ }^{\mathrm{T}}$ \\
\hline HIS10-2 & $\mathrm{A} / 10$ & 60.7 & 21.6 & 30 & 91.3 \\
\hline HDB1-4 & $\mathrm{B} / 30$ & 61.7 & 31.6 & 49.0 & 90.2 \\
\hline HKS35-3 & $\mathrm{A} / 35$ & 61.2 & 45.6 & 49.4 & 78.9 \\
\hline HKS87-3 & $\mathrm{A} / 87$ & $\mathrm{ND}$ & 32.7 & 49.9 & 91.5 \\
\hline HDS4-1 & $\mathrm{B} / 120$ & 60.0 & 42.3 & 42.3 & 98.4 \\
\hline HDB5- $2^{\mathrm{T}}$ & $\mathrm{B} / 150$ & 60.2 & 41.0 & 36.1 & 100.0 \\
\hline HDS6-1A & $\mathrm{B} / 180$ & 61.6 & 40.3 & 41.5 & 84.5 \\
\hline HDS6-2 & $\mathrm{B} / 180$ & 61.3 & 24.3 & 39.8 & 83.8 \\
\hline HDS6-6 & $\mathrm{B} / 180$ & $\mathrm{ND}$ & 34.1 & 44.6 & 88.7 \\
\hline HDS7-4 & $\mathrm{B} / 210$ & $\mathrm{ND}$ & 47.9 & 43.5 & 97.1 \\
\hline HDB8-2 & $\mathrm{B} / 240$ & 61.8 & 36.7 & 38.6 & 81.1 \\
\hline HDB8-5 & $\mathrm{B} / 240$ & 61.5 & 44.4 & 46.3 & 84.2 \\
\hline HDS10-5 & $\mathrm{B} / 300$ & $\mathrm{ND}$ & 46.6 & 43.5 & 97.5 \\
\hline HDB10-5 & $\mathrm{B} / 300$ & $\mathrm{ND}$ & 41.3 & 45.7 & 86.6 \\
\hline HKS333-2 & $\mathrm{A} / 333$ & 61.7 & 35.6 & 43.0 & 85.9 \\
\hline Hcc. dombrowskii JCM $12289^{\mathrm{T}}$ & - & $61.3^{*}$ & 100.0 & $\mathrm{ND}$ & 42.3 \\
\hline Hcc. morrhuae JCM $8876^{\mathrm{T}}$ & - & $57.8 \dagger$ & 34.1 & 100.0 & 25.7 \\
\hline
\end{tabular}

ND, Not determined.

${ }^{\star}$ Data from Stan-Lotter et al. (2002).

$\dagger$ Data from Bohácek et al. (1968). 
similarities of $98.2-98.7 \%$, whereas it was more distantly related to Hcc. hamelinensis JCM $12892^{\mathrm{T}}$, Hcc. saccharolyticus JCM $8878^{\mathrm{T}}$ and Hcc. salifodinae JCM $9578^{\mathrm{T}}$, with sequence similarities of 93.7-94.1\%. DNA-DNA hybridization experiments revealed that the 15 novel strains constituted a homogeneous genetic group with more than $78.9 \%$ DNA-DNA relatedness (Wayne et al., 1987). However, the novel strains showed low levels of DNADNA relatedness $(<50 \%)$ with Hcc. morrhuae JCM $8876^{\mathrm{T}}$ and Hcc. dombrowskii JCM $12289^{\mathrm{T}}$ (Table 2). In addition, the 15 strains could be differentiated from recognized species of the genus Halococcus based on intolerance to high concentrations of $\mathrm{MgCl}_{2}$, growth at $45^{\circ} \mathrm{C}$, acid production from carbohydrates and utilization of various carbon sources (Table 1).

Based on their phenotypic and chemotaxonomic characteristics, including low levels of DNA-DNA relatedness to recognized Halococcus species, the novel strains described herein are considered to represent a novel species of this genus, for which the name Halococcus thailandensis sp. nov. is proposed.

\section{Description of Halococcus thailandensis sp. nov.}

Halococcus thailandensis (thai.lan.den'sis. N.L. masc. adj. thailandensis pertaining to Thailand, where the first strains were isolated).

Cells are Gram-negative, non-motile, strictly aerobic cocci, $0.8-1.2 \mu \mathrm{m}$ in diameter, occurring singly, in pairs, tetrads or sarcina packets. Colonies are small, red-pigmented and circular with entire margins $(1-2 \mathrm{~mm}$ in diameter after 1 week of incubation at $37{ }^{\circ} \mathrm{C}$ ) when grown on complex medium of neutral pH. No lysis in distilled water. Grows aerobically but not anaerobically even in the presence of nitrate or arginine. Grows between 15 and $45{ }^{\circ} \mathrm{C}$ (optimally

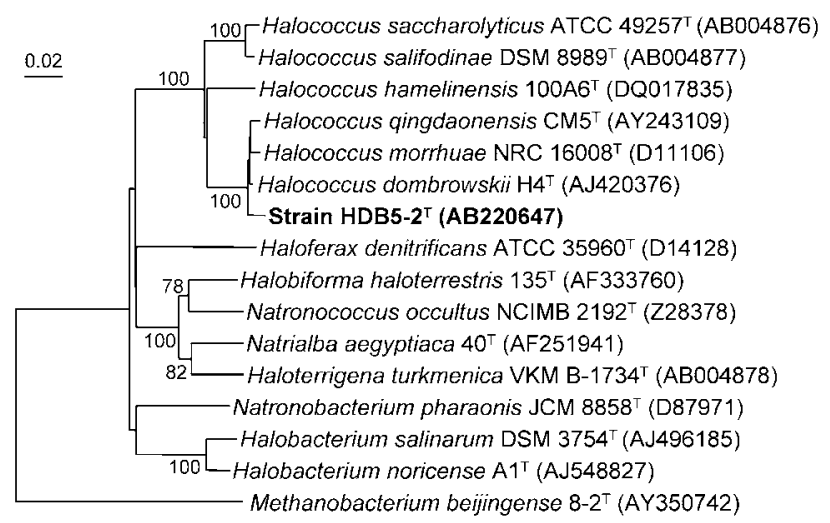

Fig. 2. Phylogenetic tree showing the relationships between strain HDB5 $-2^{\top}$ and related bacterial species based on $16 \mathrm{~S}$ rRNA gene sequences. The branching pattern was generated by using the neighbour-joining method. Bootstrap percentages $\geqslant 78 \%$, based on 1000 replications, are shown at nodes. Bar, 2 substitutions per 100 nucleotide positions. at $37^{\circ} \mathrm{C}$ ) and between pH 6 and 10 (optimally at pH 6-8). Extremely halophilic; requires at least $15 \%(\mathrm{w} / \mathrm{v}) \mathrm{NaCl}$ for growth and grows optimally at 20-30\% (w/v) NaCl. Does not require $\mathrm{MgCl}_{2}$ for growth. Catalase-, oxidase- and urease-positive. Nitrate is reduced but gas is not formed. Does not hydrolyse arginine, casein, gelatin, Tween 80 or starch. Produces acids from L-arabinose, cellobiose, Dglucose, lactose, D-mannitol, melibiose, sucrose and trehalose. Utilizes L-arabinose, D-fructose, D-glucose, Dxylose and glutamic acid, but not D-galactose or serine as the sole energy source. The type strain is susceptible to bacitracin, novobiocin and rifampicin but resistant to chloramphenicol, tetracycline, ampicillin, gentamicin, kanamycin, nalidixic acid and streptomycin. The DNA $\mathrm{G}+\mathrm{C}$ content is $60.2-61.8 \mathrm{~mol} \%$. Possesses $\mathrm{C}_{20} \mathrm{C}_{20}$ and $\mathrm{C}_{20} \mathrm{C}_{25}$ diether core lipids. MK- $8\left(\mathrm{H}_{2}\right)$ is the predominant menaquinone component. Possesses phosphatidylglycerol and phosphatidylglycerol methylphosphate as major polar lipid components. S-DGD-1, a sulfated mannosylglucosylglycerol diether, and unidentified glycolipids are also present.

The type strain, HDB5- $2^{\mathrm{T}}\left(=\mathrm{BCC} 20213^{\mathrm{T}}=\mathrm{JCM} 13552^{\mathrm{T}}\right.$ $=$ PCU $278^{\mathrm{T}}$ ), was isolated from fish sauce fermentation in Thailand.

\section{Acknowledgements}

We are very grateful to the Sindhu Samuth Fish Sauce Factory (Squid Brand) Ltd, Samutprakarn, and the Thai Fish sauce factory (Squid Brand) Co., Ltd, Samutsongkram, for providing samples. This study was supported by the Thailand Research Fund for a 2001 Royal Golden Jubilee Scholarship as a research grant to S. N. and in part by a Ratchadapiseksomphot Research Grant, Chulalongkorn University (2002).

\section{References}

Barrow, G. I. \& Feltham, R. K. A. (1993). Cowan and Steel's Manual for the Identification of Medical Bacteria, 3rd edn. Cambridge: Cambridge University Press.

Bohácek, J., Kocur, M. \& Martinec, T. (1968). Deoxyribonucleic acid base composition of some marine and halophilic micrococci. J Appl Bacteriol 31, 215-219.

Chaiyanan, S., Chaiyanan, S., Maugel, T., Huq, A., Robb, F. T. \& Colwell, R. R. (1999). Polyphasic taxonomy of a novel Halobacillus, Halobacillus thailandensis sp. nov. isolated from fish sauce. Syst Appl Microbiol 22, 360-365.

Denner, E. B. M., McGenity, T. J., Busse, H.-J., Grant, W. D., Wanner, G. \& Stan-Lotter, H. (1994). Halococcus salifodinae sp. nov., an archaeal isolate from an Austrian salt mine. Int J Syst Bacteriol 44, 774-780.

Ezaki, T., Hashimoto, Y. \& Yabuuchi, E. (1989). Fluorometric deoxyribonucleic acid-deoxyribonucleic acid hybridization in microdilution wells as an alternative to membrane filter hybridization in which radioisotopes are used to determine genetic relatedness among bacterial strains. Int J Syst Bacteriol 39, 224-229.

Felsenstein, J. (1985). Confidence limits on phylogenies: an approach using the bootstrap. Evolution 39, 783-791.

Goh, F., Leuko, S., Allen, M. A., Bowman, J. P., Kamekura, M., Neilan, B. A. \& Burns, B. P. (2006). Halococcus hamelinensis sp. nov., a novel 
halophilic archaeon isolated from stromatolites in Shark Bay, Australia. Int J Syst Evol Microbiol 56, 1323-1329.

Grant, W. D. (2001). Genus Halococcus Schoop 1935a, 871 ${ }^{\mathrm{AL}}$. In Bergey's Manual of Systematic Bacteriology, 2nd edn, vol. 1, pp. 311-314. Edited by D. R. Boone, R. W. Castenholz \& G. M. Garrity. New York: Springer.

Grant, W. D. \& Larsen, H. (1989). Group III. Extremely halophilic archaeobacteria. Order Halobacteriales ord. nov. In Bergey's Manual of Systematic Bacteriology, vol. 3, pp. 2216-2219. Edited by J. T. Staley, M. P. Bryant, N. Pfennig \& J. G. Holt. Baltimore: Williams \& Wilkins.

Kocur, M. \& Hodgkiss, W. (1973). Taxonomic status of the genus Halococcus Schoop. Int J Syst Bacteriol 23, 151-156.

Komagata, K. \& Suzuki, K. (1987). Lipid and cell wall analysis in bacterial systematics. Methods Microbiol 19, 161-207.

Kumar, S., Tamura, K., Jakobson, I.-B. \& Nei, M. (2001). MEGA2: molecular evolution analysis software. Bioinformatics 17, 1244-1245.

Leifson, E. (1963). Determination of carbohydrate metabolism of marine bacteria. J Bacteriol 85, 1183-1184.

Minnikin, D. E., O'Donnell, A. G., Goodfellow, M., Alderson, G., Athalye, M., Schaal, A. \& Parlett, J. H. (1984). An integrated procedure for the extraction of bacterial isoprenoid quinones and polar lipids. J Microbiol Methods 2, 233-241.

Montero, C. G., Ventosa, A., Rodríguez-Valera, F., Kates, M., Moldoveanu, N. \& Ruiz-Berraquero, F. (1989). Halococcus saccharolyticus sp. nov., a new species of extremely halophilic non-alkaliphilic cocci. Syst Appl Microbiol 12, 167-171.

Namwong, S., Tanasupawat, S., Smitinont, T., Visessanguan, W., Kudo, T. \& Itoh, T. (2005). Isolation of Lentibacillus salicampi strains and Lentibacillus juripiscarius sp. nov. isolated from fish sauce in Thailand. Int J Syst Evol Microbiol 55, 315-320.

Oren, A., Ventosa, A. \& Grant, W. D. (1997). Proposed minimal standards for description of new taxa in the order Halobacteriales. Int J Syst Bacteriol 47, 233-238.

Saito, H. \& Miura, K. (1963). Preparation of transforming deoxyribonucleic acid by phenol treatment. Biochim Biophys Acta 72, 619-629.

Saitou, N. \& Nei, M. (1987). The neighbor-joining method: a new method for reconstructing phylogenetic trees. Mol Biol Evol 4, 406-425.

Schoop, G. (1935). Halococcus litoralis, ein obligat halophiler Farbstoffbildner. Dtsch Tierarztl Wochenschr 43, 817-820 (in German).
Stan-Lotter, H., Pfaffenhuemer, M., Legat, A., Busse, H.-J., Radax, C. \& Gruber, C. (2002). Halococcus dombrowskii sp. nov., an archaeal isolate from a Permian alpine salt deposit. Int J Syst Evol Microbiol 52, 1807-1814.

Tamaoka, J. \& Komagata, K. (1984). Determination of DNA base composition by reversed-phase high-performance liquid chromatography. FEMS Microbiol Lett 25, 125-128.

Tanasupawat, S. \& Komagata, K. (2001). Lactic acid bacteria in fermented foods in Southeast Asia. In Microbial Diversity in Asia, Technology and Prospects, pp. 43-59. Edited by B. H. Nga, H. M. Tan \& K. Suzuki. Singapore: World Scientific Publishing.

Tanasupawat, S., Shida, O., Okada, S. \& Komagata, K. (2000). Lactobacillus acidipiscis sp. nov., and Weissella thailandensis sp. nov., isolated from fermented fish in Thailand. Int J Syst Evol Microbiol 50, 1479-1485.

Tanasupawat, S., Pakdeeto, A., Namwong, S., Thawai, C., Kudo, T. \& Itoh, T. (2006). Lentibacillus halophilus sp. nov., from fish sauce in Thailand. Int J Syst Evol Microbiol 56, 1859-1863.

Thompson, J. D., Higgins, D. G. \& Gibson, T. J. (1994). CLUSTAL W: improving the sensitivity of progressive multiple sequence alignment through sequence weighting, position-specific gap penalties and weight matrix choice. Nucleic Acids Res 22, 4673-4680.

Thongsanit, J., Tanasupawat, S., Keeratipibul, S. \& Jatikavanich, S. (2002). Characterization and identification of Tetragenococcus halophilus and Tetragenococcus muriaticus strains from fish sauce (nampla). Jpn J Lactic Acid Bacteria 13, 46-52.

Thongthai, C., McGenity, T. J., Suntinanalert, P. \& Grant, W. D. (1992). Isolation and characterization of an extremely halophilic archaeobacterium from traditionally fermented Thai fish sauce (nam pla). Lett Appl Microbiol 14, 111-114.

Wang, Q.-F., Li, W., Yang, H., Liu, Y.-L., Cao, H.-H., DornmayrPhaffenhuemer, M., Stan-Lotter, H. \& Guo, G.-O. (2007). Halococcus qingdaonensis sp. nov., a halophilic archaeon isolated from a crude sea-salt sample. Int J Syst Evol Microbiol 57, 600-604.

Wayne, L. G., Brenner, D. J., Colwell, R. R., Grimont, P. A. D., Kandler, O., Krichevsky, M. I., Moore, L. H., Moore, W. E. C., Murray, R. G. E. \& other authors (1987). International Committee on Systematic Bacteriology. Report of the ad hoc committee on reconciliation of approaches to bacterial systematics. Int J Syst Bacteriol 37, 463-464. 